\title{
Bullous Pyoderma Gangrenosum in a Patient with Acute Myelogenous Leukemia as a Pathergic Reaction after Bone Marrow Biopsy
}

\author{
Akut Miyelojenik Lösemili Olguda Kemik lliği Biyopsisi Sonrası Paterjik Reaksiyon Şeklinde \\ Büllöz Piyoderma Gangrenosum Gelişmesi
}

Nur Efe İris ${ }^{1,2}$, Reyhan Diz-Küçükkaya ${ }^{3}$, Mutlu Arat ${ }^{3}$, Zahide Eriş ${ }^{4}$

${ }^{1}$ Istanbul Bilim University Faculty of Medicine, Department of Infectious Diseases and Clinical Microbiology, istanbul, Turkey ${ }^{2}$ Avrupa Florence Nightingale Hospital, Clinic of Infectious Diseases and Clinical Microbiology, Istanbul, Turkey ${ }^{3}$ Istanbul Bilim University Faculty of Medicine, Department of Internal Medicine Division of Hematology, Istanbul, Turkey ${ }^{4}$ istanbul Bilim University Faculty of Medicine, Department of Dermatology, istanbul, Turkey

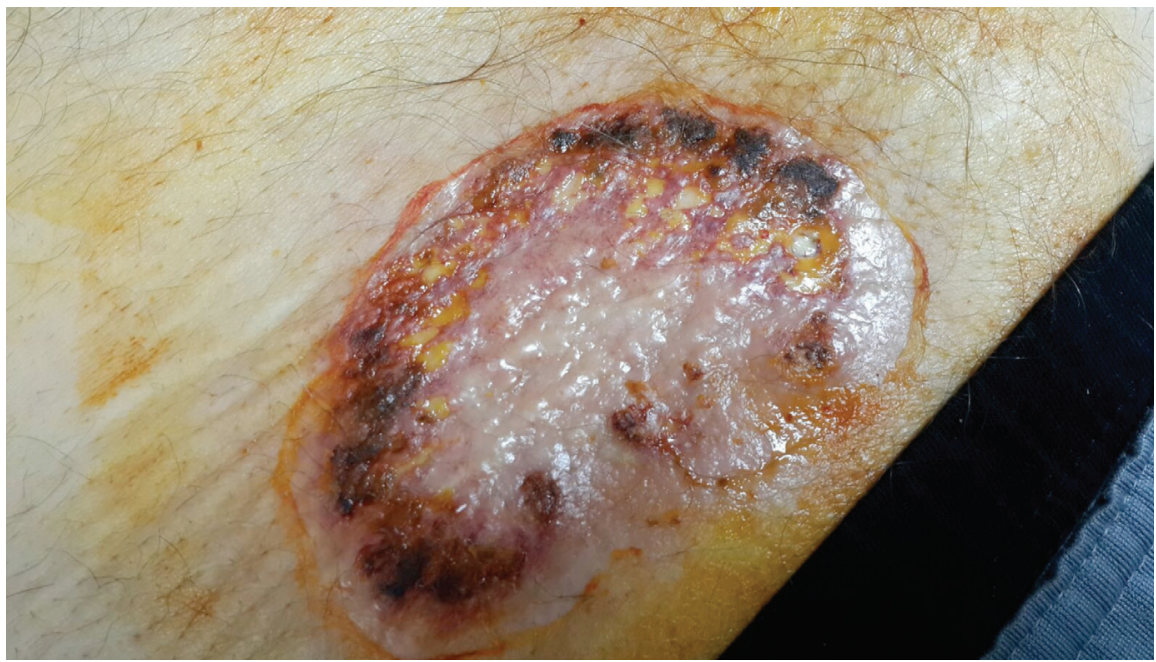

Figure 1. Bone marrow biopsy puncture area with $6 \times 4 \mathrm{~cm}$ cribriform ulceration with expanding bullous margin.

A 59-year-old male patient presented with a wound over the sacral region on a bone marrow biopsy puncture that had been present for 3 weeks (Figure 1). There was an ulceration of $6 \times 4$ $\mathrm{cm}$ with a bullous margin. Bullous pyoderma gangrenosum $(\mathrm{PG})$ was diagnosed by the dermatology consultant. Histopathologic examination of the biopsy specimen from the ulcer showed necrosis with an underlying mixed inflammatory cell infiltration within the dermis extending to the subcutis. Cultures of skin biopsies were negative for bacteria, fungi, and atypical mycobacteria. A bone marrow biopsy showed acute myelogenous leukemia (AML) transformed from myelodysplastic syndrome.

PG is an uncommon neutrophilic ulcerative skin disease. In contrast to its name, $\mathrm{PG}$ is neither an infectious nor a gangrenous condition. Pathergy is commonly observed, especially after

๑Copyright 2017 by Turkish Society of Hematology

Turkish Journal of Hematology, Published by Galenos Publishing House

Address for Correspondence/Yazışma Adresi: Nur EFE IRIS, M.D.,

İstanbul Bilim University Faculty of Medicine, Department of Infectious Diseases and Clinical Microbiology, İstanbul, 
debridement of a lesion [1,2]. In $P G$ there is an excessive inflammatory reaction to trauma of the skin by a needle. In this case there was a pathergic reaction after bone marrow biopsy.

Definitive diagnosis requires both clinical recognition and exclusion of infectious or neoplastic disorders [3]. PG is usually associated with an underlying systemic disease $[1,4]$. Based on clinical morphology, PG is classified into four variants: ulcerative, pustular, bullous, and vegetative [5]. Bullous PG is commonly associated with myeloproliferative diseases [5]. Association with leukemia signifies a poor prognosis [5].

Our patient was in remission for $A M L$, he underwent allogeneic hematopoietic stem cell transplantation, and the $P G$ resolved completely.

Keywords: Acute myelogenous leukemia, Bullous pyoderma gangrenosum, Pathergy

Anahtar Sözcükler: Akut myeloid lösemi, Büllöz piyoderma gangrenosum, Paterji
Informed Consent: It was received.

Conflict of Interest: The authors of this paper have no conflicts of interest, including specific financial interests, relationships, and/or affiliations relevant to the subject matter or materials included.

\section{References}

1. Fox PL, Geyer AS, Husain S, Grossman ME. Bullous pyoderma gangrenosum as the presenting sign of fatal acute myelogenous leukemia. Leuk Lymphoma 2006;47:147-150.

2. Bennett $M L$, Jackson JM, Jorizzo JL, Fleischer $A B$ Jr, White $W L$, Callen JP. Pyoderma gangrenosum. A comparison of typical and atypical forms with an emphasis on time to remission. Case review of 86 patients from 2 institutions. Medicine (Baltimore) 2000;79:37-46.

3. Callen JP, Dubin HV, Gehrke CF. Recurrent pyoderma gangrenosum and agnogenic myeloid metaplasia. Arch Dermatol 1977;113:1585-1586.

4. Srivastata $M$, Rencic A, Nousari HC. A rapidly expanding ulcer. Myelodysplastic syndrome-associated (paraneoplastic) pyoderma gangrenosum. Arch Dermatol 2003;139:531-536.

5. Powell FC, Su WP, Perry HO. Pyoderma gangrenosum: classification and management. J Am Acad Dermatol 1996;34:395-409. 